\title{
Impossible Research? Ethical Challenges in the (Digital) Study of Deportable Populations Within the European Border Regime
}

\section{Leandros Fischer and Martin Bak Jørgensen}

\section{INTRODUCTION}

Some time ago, during our DIGINAUTS project, one of the authors of this contribution attended an important migration conference on the digitalisation of bordering practices. His presentation dealt with the digital strategies of those potentially facing deportation. After elaborating on some basic findings of our research among precarious migrants in Hamburg and northern Denmark, he proceeded to show some translated comments and postings from a Facebook group, here called platform.

L. Fischer

Hamburg, Germany

e-mail: fischer@hum.aau.dk

M. B. Jørgensen $(\bowtie)$

Department for Culture and Learning, Aalborg University, Aalborg, Denmark e-mail: martinjo@hum.aau.dk

(C) The Author(s) 2022

M. Sandberg et al. (eds.), Research Methodologies and Ethical Challenges in Digital Migration Studies, Approaches to Social Inequality and Difference, https://doi.org/10.1007/978-3-030-81226-3_6 
This was a closed, Arabic-language group of about 330,000 members, which was mentioned during one of the qualitative interviews for our research. Our project assistant, an Arabic native speaker, requested access to the group, which was immediately granted. She then selected some posts and comments, anonymised them, and created a folder for the project. The co-author presented these comments as an example of various migrant strategies that not only pointed to linear journeys towards preferred destinations but were indicative of multiple sojourns in different European countries due to long waiting periods of application processing or rejection, as well as return journeys. In line with our approachgrounded largely on the Autonomy of Migration (AoM) concept-the co-author intended to highlight the creativity and ingenuity of migrants who-despite all odds-managed to find ways to circumvent restrictive bordering practices. It was an effort to emphasise agency, rather than victimhood.

Nevertheless, the audience was not overly receptive to this point of view. During the discussion, methodological questions arose. One participant in particular asked whether our student assistant had notified the group members that she was conducting research within the closed group. The co-author replied that such a thing would be of no use in a group of 330,000 , where queries are deleted as soon as they are adequately answered. Instead of satisfying the discussion participant, this answer only seemed to agitate him, as well as other people in the room. "How do you know that your data are not being collected by FRONTEX [the European agency tasked with guarding the continent's militarized borders]?" The co-author replied that, given the ease with which access to the group could be gained, FRONTEX would already have placed informants within the platform. The co-author sensed that he was not personally satisfied with his answer. Indeed, how could we be sure that our data-indicating ways of circumventing border restrictions-would not ultimately be used against migrants? The discussion ended with no conclusion.

This contribution is one attempt to answer some pressing methodological as well as ethical dilemmas of digital research with vulnerable groups. How does one conduct research that aims to highlight the agency of migrants without inadvertently placing them in danger? How is the question of inherently uneven power differentials played out in this case? And doesn't the overwhelming majority of social science fieldwork and qualitative research involve unequal power relations almost by definition? There are certainly more papers published on refugees, urban slum dwellers, 
or oppressed minorities than, let's say, on politicians, representatives of the finance industry, or top-brass military officers. This is partly because the former group is infinitely more approachable than the latter, who is concealed in gated communities, high-rise luxury apartments, or military bases.

This chapter departs from our work within the DIGINAUTS project (see Sandberg and Rossi, Introductory chapter to this volume). The purpose of this project was to investigate how information and communications technology (ICT), the digital practices of migrants as well as of aiding organisations and initiatives of the receiving countries intermediate and constitute new sociotechnical networks of community and solidarity, in turn re-enacting migrants as political subjects in/of the European border regime. As a subproject, the two authors of this chapter were involved in and focused on the Danish-German borderland. In 2015, more than 21,000 people applied for asylum in Denmark (Udlændinge-, Integration- og Boligministeriet 2016). Many used Denmark as a pathway to reach Sweden before border controls were enforced. In 2015, Germany received over one million claims for asylum and large numbers passed through the country to get further north. Hamburg has long been a hub for especially Sub-Saharan migrants coming to Hamburg via Libya and Lampedusa (Jørgensen 2019).

Digital connectivity has been important for both the migrants staying in Germany trying to find information on rights, housing, work, legal help, and civil society groups and aid workers, and for the migrants seeking to enter Scandinavia. During the subproject, we conducted fieldwork in Hamburg and various places in Denmark to compare patterns in ICT use and survival strategies between the latter group and the recent incoming groups-especially from Syria.

Very soon after initiating the project and beginning work on the subproject, we faced a new situation. In several European countries today, we can identify a paradigm shift from migrant integration to the securitisation of migration and deportation. In Denmark, the government has generally stepped-up deportations and we are witnessing an expansion of the category of deportable populations. This politicisation of immigration in Denmark has caused enormous insecurity among migrants. Similar tendencies can be observed in Germany, where the end of political Willkommenskultur by the state has been met with an increase in deportations to Afghanistan and the Balkans. This means that potential deportees and undocumented migrants must increasingly develop survival strategies 
for if and when they are deported. Furthermore, migrants are starting to share information and strategies online on how to return to Turkey and the Middle East. In the case of Denmark, we are seeing a still increasing number of people disappearing from the authorities' radar, going to other European countries and living as irregular migrants or attempting to apply for asylum through loopholes in the Dublin agreement. This development led us analytically towards a focus on anti-deportation. The change of focus also developed into methodological and ethical issues and a self-investigation on how to work on these issues.

Departing from the issues outlined so far, this chapter asks how we (as researchers) collect data, how we engage with our informants, how we disseminate our results, and what we seek to achieve by and through our research. The chapter is structured as follows. Firstly, we discuss migration research ethics and the various challenges we identify here. We use this discussion to reflect on the polarising effects of politicised research and how to take a stance. Secondly, we engage in a critical debate with the principle of "doing no harm" and ask if it is possible to outline a research position with the opposite goal, i.e. making the repressive and destructive features of the border regime visible. Here, we highlight two different approaches: the militant research approach and the AoM approach. In short, militant research is a politically engaged research practice that seeks to be capable of articulating involvement and thought. AoM can be best described as an attempt to theorise the role of migrant agency in the constitution of contemporary border regimes (Fischer and Jørgensen, forthcoming a). Its emphasis is placed on the primacy of movement over control (Bojadžijev and Karakayali 2010; Karakayali and Tsianos 2010; Mezzadra 2011), as well as the development of socialities and mundane practices independent of sovereign control among people on the move, dubbed the "mobile commons" (Fischer and Jørgensen, forthcoming a; Papadopoulos and Tsianos 2013). The AoM the approach "seeks to reinterpret the effects of seeing regular, irregular, transit and other forms of migration as constitutive factors of border policies, architectures, and practices" (Casas-Cortes et al. 2015, 897). Or in simpler terms and conclusively, the approach makes mobility and migration the starting point of analyses and conceptualises migrants as having agency (Agustín and Jørgensen 2019). In our work on DIGINAUTS, the militant research perspective has influenced our methodological grounding and the AoM has guided our conceptual and theoretical perspectives (see also Galis in Chapter 7 of this volume). Thus, the third section of this 
chapter engages with the militant research approach and discusses how and if the departure from a politically committed approach also offers an ethical research strategy, i.e. politically engaged as ethics. Fourthly, we bring in the AoM approach and, along similar lines, discuss how the principles of AoM influence our methodology and intentions with our research. In the final part of the chapter, we combine these perspectives and situate our own research studies in a final discussion.

\section{Migration Research Ethics}

In the migration research literature, ethical issues are very often brought to the forefront. As stated by other scholars (e.g. Yalaz and ZapataBarrero 2018; Zapata-Barrero and Yalaz 2020) the research context is key here, as qualitative migration studies very often involve being in contact with people whose migratory experiences can have very different characteristics. There is a world of difference between studies of Western retirees in Indonesia (Bell 2017), Swedish retirement migrants living in precarious conditions in Spain (Gavanas and Calzada 2016), the privileged mobilities of expats residing in Paris, Singapore, and Bangalore (Polson 2016) and studies on migrants with trajectories characterised by traumas, abuse, and even torture (Nimführ and Sesay 2019; Van Liempt and Bilger 2018). All such studies require ethical research virtues. However, the differences and the stakes that are embedded in these studies force us to ask where to draw the ethical lines between risking interlocutors' safety and pursuing our own research ends, in direct contrast, for instance, to medical research, where such issues are keenly debated (Düvell et al. 2010). Despite the necessity to explicitly draw this line-in migration studies-Düvell et al. have argued that this rarely happens (2010). Picking up on the claim made by Düvell et al., Zapata-Barrero and Yalaz (2020, 2) formulate the basic questions we need to ask:

These questions now need to be considered as key-issues belonging to the same research design process: How do we ethically carry QR [qualitative research] with migrants? How do we solve particular ethical situations and dilemmas? How do we identify and manage ethical risks in conducting QMR [qualitative migration research]? What has to be the reference framework for assessing ethical risks? Do these ethical considerations affect the quality and objectivity of the research? Are universal ethical codes of conduct applied to QMR enough for dealing with particular situations? 
These questions are also addressed in the literature (e.g. Birnie 2019; Rodgers 2004; Siapera and Creta 2020; Van Liempt and Bilger 2009, 2018). The questions call for both an ethical awareness and an ethical reflexivity in regards to how we (as researchers) collect data, how we engage with our informants, how we disseminate our results, and what we seek to achieve by and through our research. Again, none of the reflections that we raise here are novel when considered in isolation. These are issues with a long academic trajectory and debate within ethnology, ethnography, and social anthropology. Within anthropology and ethnography, these issues are part of a reflexive turn (e.g. Clifford and Marcus 1986; Foley 2002). This turn has emphasised how the person of the anthropologist can affect the ethnographies they write and has forced anthropologists to tell the story of their integration and interactions within the community they were studying (e.g. Venkatesh 2013). This kind of awareness and reflexivity can be broken down into various issues.

Firstly, as already mentioned, there is a categorical difference in the kind of ethnical reflexivity needed when studying migrants who have voluntarily entered migration (can be both privileged and non-privileged migratory processes and statuses) and those who have entered the migratory process in vulnerable and precarious circumstances. The latter is especially true when we contemplate the field of migration and include illegalised migrants without recognised papers, people living in camps, racialised minorities, rejected asylum seekers, people facing deportation, having been trafficked, and similar vulnerable and precarious situations. Here, we need to acknowledge and account for inequalities and power dynamics. The problem is, however, that these categories of migrant statuses are not self-evident and do not give us a fixed answer to the question of which migrant groups to work with and how. Categories of difference have a crucial position in academic research as well as policymaking. They serve to distinguish and differentiate between groups in society. They can appear in the form of crude dichotomies or in complex and sophisticated forms resting on constructivist and intersectionalist perspectives. Nevertheless, using categories of difference also causes something to exist and there may be implications through the particular application of specific categories (Jørgensen 2012). Put more simply, categories and their definitions matter. Categories of race, ethnicity, gender, or social divisions are all categories of difference, which serve to position the particular individual or group in a social and economic location. Similarly, what is common for most of the different academic approaches-despite 
disciplinary demarcations and intentions of wanting to analyse discrimination, marginalisation, or inequalities, for instance-is that in order to study immigrants and ethnic minority communities, the focus necessarily ends up highlighting differences. In order to enter this research field, studies inevitably reproduce various distinctions between "us" and "them". Academic approaches "write differences", so to speak, into the texts they produce (Nayak 2006; Rosenblum and Travis 2008). Research may itself construct categories of difference, for instance, by racialising research (Ali 2006).

As also addressed by Zapata-Barrero and Yalaz, this difference in what and whom we study relates to a second debate between the quality and objectivity of the research and thinking ethically $(2020,2)$. In the literature, thinking ethically has been discussed through three ethical universal provisos: do no harm; respect autonomy; and ensure equitable sharing of benefits (ibid.; Flick 2018; Krause 2017). Likewise, these ethical provisos are not adequate for describing the participatory actionresearch approaches that aim at intervening and spurring social change. We will return to this part of the discussion below, however, an initial argument here is that migration research is a normative activity that refers to conscious social and political engagement. This engagement must be able to deal with both potential harms and benefits (Düvell et al. 2010).

Thirdly, there is the issue of how we disseminate research. The ambition of producing knowledge that can be used by social actors, including migrants themselves, to reveal exploitation and repression and improve their conditions is also put at risk of being abused by anti-immigrant forces, states, and security agents. Our initial vignette is a good example of this dilemma. We can find attempts to develop best practices in the literature. In their work on irregular migration, the aim of Düvell et al. has: "Not been just to produce a 'body of knowledge' but to address the misperceptions and misconceptions surrounding irregular migration, and to minimise the risks and maximise the benefits, firstly for the researched group and, secondly, for other stakeholders" (2010, 228-229). They continue later in the article by raising a number of both hypothetical and practical questions:

Should all or only some results be published? Who is the audience? How will our results be received and discussed at a given time period (in the light of related political and public debates) and how may they be (ab)used? The question also arose as to what extent we can control and influence the (ab)use of our findings. (ibid., 235) 
Having worked on irregular migration ourselves, we recognise these challenges and dilemmas. One of the co-authors of this chapter ended up experiencing the political implications of producing and disseminating research knowledge. Following the publication of an edited volume on irregular migration in Scandinavia (Thomsen et al. 2010), the immigrantcritical Danish People's Party called for increased control as a consequence of the research results. Emphasising that there is no exact information about the number of irregular migrants does not help, as numbers rapidly gain an existence of their own. The development in Denmark at the time provided an interesting example.

Before 2012, the Danish police estimated that there were around 5000 irregular migrants in Denmark, but in 2012 the estimate soared to between 20,000 and 50,000 irregular migrants in the country (Glerup 2012). The estimate was not based on any research project or new methodology but on three interviews with anonymous sources within the police (Glerup 2012). Nevertheless, this number was reproduced by the national public and private media (e.g. Fahrendorff 2012) and ultimately became part of the Danish People's Party's lst of May Campaign (in 2012) - "Do something about the large number" $(40,000)$ of irregular migrants they advocated for (see Thomsen and Jørgensen 2012). An unintended consequence was that our research was used to legitimise a call for restrictions and penalise practices. Disseminating research results not only includes the dilemma of making sensitive knowledge available for security agents and the police and penal systems but also the risk of being politicised towards aims over which the researcher has no control.

Fourthly, we must consider the aims and purposes of our researchand if these contribute to social and political change towards equality and social justice. When it comes to qualitative ethnographic work, there has been a long debate regarding the ethics of research with vulnerable groups. Migratory experiences characterised by vulnerability and precarity fall under this discussion. Ultimately, these are not only questions of ethics but an epistemological question about the choice and standpoint of the researcher in regards to the purpose and value of knowledge. In the article "'Stop Stealing Our Stories': The Ethics of Research with Vulnerable Groups", Pittaway et al. (2010) discuss some challenges and opportunities facing those working to integrate participatory methods into human rights-based research. Their article draws on refugees' experience to analyse how interviewees perceive the interaction with and (lack of) trust in researchers, emphasising three interdependent 
issues: risks, distrust, and hierarchical distances. They discuss an approach they have designed for working with communities and individuals experiencing multiple oppressions and persecution. This approach reflects the principles of anti-oppressive social work and the ethics of undertaking research with vulnerable populations (ibid.). The relationship between the researcher and people in vulnerable positions, in our case migrants at risk of deportation, is definitely unequal. As Düvell et al. write about their work with irregular migrants, such persons, despite the asymmetrical relationship, nevertheless hold a position of key influence in the research context, namely the ability to decide whether or not to tell their stories and participate in the research $(2010,233)$. This holds some truth but as Düvell et al. also explain, informants can easily misinterpret the role and potential influence of the researcher and choose to talk with researchers, believing those researchers have the power to improve their position. We recognise such relationships and encounters in our own work. One of the co-authors visited an informant at a deportation centre, not to conduct interviews but to follow up on the well-being and situation of that person. However, rumours immediately spread that he was there to help people with their asylum cases and a number of other women at the centre lined up to tell their stories in the hope of receiving help. Although, in an unpredicted way, such a situation can end up generating important data, none of these conversations were recorded or used for research. Here, the situation was not a matter of stealing people's stories but a matter of people wanting their stories to be actually heard, as the women felt that none of the staff or migration authorities had listened to them without misinterpreting what they were saying. They initially wanted to share their stories with a clear aim though - that talking to the co-author could change their asylum rejection. This is just one example of many comparable situations we have encountered, both within the DIGINAUTS project but also in previous work. It shows how, during practical work, the relatively abstract academic aims of a research project can be confronted with the lives being lived by the people we engage with. In practice, we are met with real people struggling individually and collectively who-despite the asymmetrical relationship - meet us, the researchers, with a claim that their struggles should not only be understood but that we should stand beside them and offer the help they expect us to provide to improve their situation. This represents another ethical challenge. Wissink describes this dilemma well as a gap between ethics in the phase of research design, which may be mainly inspired by 
"text-book ethics" and the ethical dilemmas a researcher may experience in the field $(2019,2)$ (for a discussion on the emotional implications of conducting research in insecure places among migrants in extremely difficult situations, see Nyberg Sørensen in Chapter 8 of this volume).

The four issues we have so far addressed in the discussion: how we (as researchers) collect data, how we engage with our informants, how we disseminate our results, and what we seek to achieve by and through our research, are all relevant, and we can evidently refer to a theme that traces back far into the literature. However, what we faced in our work were not only concerns about how to work with deportable populations but also why we were doing so. As researchers engaged in studies on sensitive and politicised issues, we often cannot avoid prompting a polarising effect. Düvell et al. point this out and continue by stating that "sometimes, our findings have been of such an explicit nature that it has proved difficult not to take sides" $(2010,236)$. Is taking sides or taking a stand a problem though? And for whom? Situating our research by drawing on militant research approaches and AoM, is obviously not a problem for the authors of this chapter, but it is nevertheless a question flagged in literature and one that deserves an answer. Düvell et al. themselves answer this rhetorical question by formulating a position:

Researchers, however, are not primarily advocates or social workers but academics, and they are subject to a set of complex responsibilities for high quality and ethical research. They have responsibilities towards their subjects, their profession, their funding bodies and society at large. In our case this meant we had to negotiate a balanced attitude between contrasting perspectives and opposing aims and interests. (ibid.)

For Düvell and Triandafyllidou, the path has been to pursue advocacy from an NGO platform rather than from academia and engage in a kind of public sociology (cf. Burawoy 2005). We can follow the position outlined here and likewise the personal stances taken by those authors. At the same time, this discussion opens up a range of new questions. Is there the scope for a critical or activist engagement within academic knowledge production? How can the effects of crushing machinery such as the FRONTEX and EU border regimes with their increased militarisation be described and analysed while at the same time avoiding revealing tactics and strategies used to circumvent and transgress borders? How can we respect and 
acknowledge vulnerability while at the same time wanting to avoid victimisation and take the agency of migrants seriously? Is it possible to adhere to some kind of militant research ethics and what are the costs for the people we engage with who are in a different position to ourselves? Is it possible to write about such issues in a way that does not harm our informants but similarly does not harm an abusive, repressive, exclusionary, and dehumanising migration system that is constructing and controlling deportable populations? In the next part of the chapter, we discuss the possibility of such an approach that situates research ethics as part of research politics and we identify our own position as researchers.

\section{From "Do No Harm" to "Do a Lot of Harm"-Towards Politics of Critical Ethics}

In their protest anthem "Killing in the Name" from 1992, the US alternative rock band Rage Against the Machine takes a stance against racism and abuse of power and calls for a revolution by repeating the line "Fuck you, I won't do what you tell me" over and over. Anyone old enough to have been to one of their shows or been on the dance floor when the song was played will recognise the urge to destroy the world around you and create an alternative order. Having worked with people who have experienced the effects of the European border regimes (cf. Stierl 2018) almost inevitably makes you want to take sides and engage in research practices that could help confront and challenge this system. However, destroying the system is not a real option and not a purpose that will bring home much funding from universities or external funders. Moving on from this playfully deliberate provocative stance, we can discuss how it is possible to move towards an engaged and critical research position.

Here, we return first to the ethical dictum of "do no harm". Often considered the golden rule of research ethics, it is also considered insufficient by migration researchers (e.g. Block et al. 2013; Pittaway et al. 2010; Zapata-Barrero and Yalaz 2020). Writing about the ethics of media research with refugees, Siapera and Creta unfold this argument:

Ethical positions alone are not adequately equipped to address the problems that refugees in detention are facing. For us, the authors of this chapter, occupying the positions of media workers, activists and researchers at the same time involves contradictions that we are unable to address in purely ethical and moral terms, by invoking vague ethical principles such as 'do no harm' or 'protect vulnerable people'. $(2020,236)$ 
The problem is that merely following "procedural no-harm procedures" (e.g. blindly following formal procedures of confidentiality and privacy)—as Zapata-Barrero and Yalaz $(2020,6)$ formulate it-can still cause harm to sensitive populations if researchers do not critically evaluate the rising ethical issues. Secondly, this approach does not guarantee or contribute to enabling participation of vulnerable and hard-toreach populations. They rightly - in our opinion-claim that migration researchers not only have a duty to protect migrants but also to empower them (ibid.). A viable strategy is perhaps not to listen to "Killing in the Name" but to revisit the 1976 Fleetwood Mac classic "Go Your Own Way". Is it possible to develop an ethical research position that both aims at doing no harm to the people engaged in the study and, at the same time, working for social and political change and ultimately standing in solidarity with the people at risk of deportation? Jacobsen and Landau (2003) quote Turton for contending that, "researching other people's suffering can only be justified if the research explicitly aims at alleviating that suffering" (Turton 1996, 96, in Jacobsen and Landau 2003).

In a recently published article, Stierl makes the case for an engaged scholarship that does not shy away from intervening in the contested field of migration with the intention not to fix but to amplify the epistemic and other crises of the European border regime (2020). In the article, Stierl argues that Migration Studies tends to reify and fetishise epistemic objects such as "migration" and "migrants" (here quoting De Genova et al. 2018, 257) (ibid., 8). Stierl also contends that, for instance, cartographic representations such as those constructed by FRONTEX, are not neutral but have concrete human consequences (see also the work of Van Houtum and Lacy 2020) and likewise, that migration statistics (like maps) account for the subjective experiences of borders (Stierl 2020, 10).

Stierl criticises the "do no harm" principle as being inadequate and asks if it should not also be expanded to engagements with policymakers. Stierl ends by discussing epistemic interventions that can produce counterempirics in order to expose the violence of the EU border regime. In his concluding reflections, he discusses the impact of an activist engagement as a way to produce critical knowledge on migration and concludes that: 
Maybe the 'do no harm' principle needs to not merely be expanded to include engagements with the makers of migration policies, it may need to be reversed. Do harm could be the motto for a critical and impactful scholarship of migration that locates, and expands, ruptures in the EUropean border regime. (ibid., 16; italics in original)

Is it possible to take a research position here that actually seeks to do harm (moving from Fleetwood Mac back to Rage Against the Machine), while, at the same time, respecting the credos of (still) doing no harm to the people we work with, respecting autonomy, and ensuring equitable sharing of benefits? In the next sections, we describe and discuss two different research approaches, namely a militant research/militant anthropology approach and the AoM approach and discuss the kind of ethical positioning these two approaches offer.

\section{Militant Research as an Ethical Research Strategy}

Previously, we discussed if taking sides in a field of politicised research constitutes a methodological and/or ethical problem. From a militant research perspective, this is a futile discussion. The starting point for militant research is not an academic researcher seeking to further a particular strand of knowledge, but the context of political struggle itself (Halvorsen 2015). Militant research "is an intensification and deepening of the political", claim Shukaitis and Graeber $(2007,9)$. As an approach, militant research sees research and activism as co-constituted and is oriented solely "by invested militant activists for the purpose of clarifying and amplifying struggle" (Team Colors Collective 2010,3). Militant research connects to other engaged and militant approaches within anthropology, ethnography, and sociology (see Jørgensen 2019). Scheper-Hughes' seminal work in 1995 called for a "militant anthropology" and the "primacy of the ethical", and for anthropologists to become morally and politically engaged. Juris coined the notion of "militant ethnography" to describe this approach. He depicts this as "developing a model of politically committed ethnographic research that uses engaged ethnography as a way to contribute to movement goals while using my embedded ethnographic position to generate knowledge of movement practices and dynamics" (Juris n.d.; see also 2007, 2014). Mathers and Novelli call for an engaged ethnography (2007). These positions originate in different disciplines but pursue the same goal: solidarity with the research subjects and a research 
praxis that produces knowledge on how micro-processes of resistance are linked to macro-processes of repression (be it against neoliberal globalisation or the border regimes) (Mathers and Novelli 2007). This is both a political and ethical stance. A militant research position in this way highlights engagement, the priority of the ethical (as in committed research), possible interventions and disruptions in the field we study, and solidarity between citizens.

We have continued this kind of political engagement in our current research project. Understanding migrants' practices against deportation (Fischer and Jørgensen, forthcoming b) also necessitates an understanding of the EU border regimes and their effects. We have combined our ethnographic approach with a methodology from political ethnography. The latter makes it possible to interpret the legal and policy framework and to capture dynamics and relations beyond and outside the policy frameworks themselves and is becoming an increasingly popular approach for understanding politics and government (Boswell et al. 2019). From a policy-analysis perspective, it opens a window into the micro aspects of politics (Kumar 2014). The methodological aim here is not to identify causal inference (a common aim in mainstream political science) but rather interpretation and edification. Pursuing the militant research approach is not equal to conducting some kind of vigilante crusade against the oppressors or sailing under a black flag in all our academic and personal doings-we are not claiming to save the world but insist on engaging in critical research that is not objective but politically committed. Mathers and Novelli pick up on Scheper-Hughes and argue: "[T]he ethnographer [here broadly researcher] may find many paths to ethical and political commitment, but each of them involves him/her in undertaking a variety of acts of solidarity" $(2007,245)$.

Solidarity is also an ethical commitment that entails concrete (research) practices. In our work on the DIGINAUTS project, we followed the standard ethical guidelines and have done what we could to ensure informed consent and avoid any risk of harm to our informants. This became especially important when interlocutors were telling us about strategies on how to avoid deportation or tactics used to re-apply for asylum elsewhere. We have also engaged with our informants and changed our research focus towards what was important to them (as we started to understand the hardship faced by people at risk of deportation) rather than maintaining the focus on the trajectory from outside Europe to the German-Danish borderland and tried to produce knowledge that 
emphasises their struggles. In practice, we have used very open questions, allowing the interlocutors to be in control of what was important, which stories to tell and in defining what it means to be at risk of deportation. They have told us what to look at, which directions we should pursue, what was not relevant, and what they wanted to happen. We have not tried to (and would not have been able to) change the outcomes of their claims for asylum. However, we have connected people with other people in similar conditions and people in solidarity. We have told them of physical and digital resources (such as legal aid and networks helping people facing deportation) and passed on other people's experiences. Like the people we have met, we have engaged in political struggles, in our own way-through writing and dissemination. We do not claim to be in a comparable position, as none of the authors were or are in danger of deportation, but we took sides and stand alongside people in struggle. For us, this signals a move from ethics as a specific research practice based on ethical provisos to a political position where research is situated in politics and based on an imperative to act-one way or another.

Research has the purpose of making repressive and unjust structures visible. Instead of focusing attention solely on the individual stories and micro-forms of resistance, one aim can be to reveal the structures that create repression and destitution (also following Stierl). When rejected asylum seekers at the deportation centre Kærshovedgaard in Denmark began a hunger strike to draw attention to their suffering, we supported their struggles through our writing and the privileged platform to which academics have access. The movement, initiated by refugees, aimed to publicise the consequences of the politics of dehumanisation; politics that "kill slowly" and that are structurally produced and legitimised by law. Our, self-proclaimed, role here was to conduct a political analysis of the system producing these effects and communicate the experiences of the people trapped in this system (e.g. as in Jørgensen et al. 2018). Two years later, the situation had not been improved and people residing at Kærshovedgaard asked us again to help share their stories with the public.

\section{Autonomy of Migration and Research Ethics}

In our work on migrants' physical and digital strategies against deportation, we draw on an approach stressing autonomy, namely the AoM approach. In the book Border as Method, Mezzadra and Neilson (2013) 
go on to demonstrate how the proliferation, mobility, and deep metamorphosis of borders are key features of "actually existing" processes of globalisation. Their book builds on the AoM approach (e.g. Bojadžijev and Karakayali 2010; De Genova 2017; Papadopoulos and Tsianos 2013) and they draw on these ideas "to frame the border epistemologically and methodologically in order to develop a conjunctural analysis of current capitalist configurations" (Casas-Cortes et al. 2015, 897). This links the reading of borders to multi-scalar processes of political geography (ibid.). The AoM approach makes mobility and migration the starting point of analyses and conceptualises migrants as having agency. In this way, borders follow migration and not the other way around by constituting collective action that challenges institutional power to reshape the border regime (Mezzadra 2011). Migration here is akin to a social movement.

Our investigation of anti-deportation strategies is based on elements from AoM, and specifically the concept of the "mobile commons" (Papadopoulos and Tsianos 2013; Trimikliniotis et al. 2016). For our analyses, the important aspect of these approaches is that they allow us to understand how people on the move act without ending in victimisation. Reading anti-deportation strategies with an AoM perspective allows us to identify and understand social and political spaces created by refugees facing deportation. Instead, migration is theorised as linked to the agency of migrants themselves, specifically the desire for the freedom of movement. In addition, the desire for movement should not be simply conceptualised as merely the need for social mobility, but as one also motivated by a condition of "stuckedness" and a lack of "existential mobility", the "sense that someone is going somewhere in life" (Hage 2009). The claims made by the people we met during our project denotes both a right to receive protection as well as the right to decide where to receive this protection; migrants do not simply desire the right to stay but-like those enjoying full civil rightswant to decide themselves where their place of settlement should be. As we write in a forthcoming chapter for another volume, this means that often migrants risk a secure existence in one state to live elsewhere, motivated by a sense of justice (Fischer and Jørgensen, forthcoming $b$ ).

The concept of mobile commons describes an infrastructure always in the making, and that encapsulates the innumerable uncoordinated but cooperative actions of mobile people who contribute to its making. People on the move "create a world of knowledge, of information, of tricks for survival, of mutual care, of social relations, of services exchange, 
of solidarity and sociability that can be shared and used and where people contribute to sustain and expand it" (Papadopoulos and Tsianos 2013, 190). Digital "infrastructures of connectivity" (ibid.) constitute a basic component of the mobile commons, providing those on the move with useful information, whether in the form of navigation apps, social media, online fora, or simply as "hardware", such as battery-loading docks for smartphones present along the Balkan route prior to its closure.

So far, we have underlined the normative and epistemological underpinning of the AoM approach.

For us, it has also carved out research ethics on how and why we conduct research. Here, the term ethics implies doing research that stands on the side of migrants. Papadopoulos and Tsianos also underline the importance of this axiom:

In fact, the autonomy of migration approach is only possible if it contributes to creating conditions of thick everyday performative and practical justice so that everyday mobility, clandestine or open, becomes possible. This is a form of thick justice which creates new forms of life that sustain migrants' ordinary movements. (Papadopoulos and Tsianos 2013, 192)

Analysing and understanding the mobile commons of deportable populations from one perspective can seem to clash with the (alleged) vulnerability of irregular migrants as mobile commons point to agency and spaces of emancipation (cf. Düvell et al. 2010). However, this assumption is incorrect. The aim of our approach has not been to map an existing infrastructure but to show how people in a precarious position are also not without a voice (as the hunger-strike example illustrates). Understanding physical and digital strategies against deportation helps produce counter-knowledge that becomes part of the mobile commons. Here, we are not assuming that people on the move or people facing deportation will go to academic journals, but knowledge on cracks, frictions, resistance, and solidarity also travels along other trajectories. Other people within academia engaged in migrant struggles will have access to knowledge. In its own way, research knowledge can also become part of the commons. Research knowledge is here produced with the aim of interfering with and spurring social and political change. It is engaged scholarship produced as a type of politics articulated by both deportees and researchers by different means. 


\section{How to Study Deportable Populations-Impossible Research or Political Research}

Our work on studying deportable populations within the EU border regime has led us to work with different types of data and methodologies. We have both pursued ethnographic on-site fieldwork as well as looking into digital strategies. The ethical challenges of digital research revolve around the disconnectedness between identity and bodies and are fraught with both danger (surveillance) and opportunity/agency (mobile commons, AoM). This challenges researchers: not just to protect and do no harm but also to realise that the internet has different rules.

One of the insights we gained from the project was that the better and more protected the social position of migrants (by civil society) (e.g. Germany), the more complicated it was to gain access to them (arrangements with churches, building trust). Researchers should embrace or at least accept potential hurdles that can make it more difficult/slower to find the necessary interlocutors and encourage them to talk, due to the fact that the research subjects in question are better protected and more aware of their rights. This contrasts, for example, with refugee camps or makeshift transit locations in peripheral countries (e.g. Greece), where researchers may have easier access to vulnerable populations as their presence is very visible-although it does not follow from this that anyone residing there would want to talk to researchers doing fieldwork nor that the government would allow researchers access (on access see Rozakou 2019). Obviously, trying to access either group demands ethical reflections and sensitivity and self-reflections on the purpose of talking to either group. In the DIGINAUTS project, participating researchers deliberately refrained from interviewing in hotspots or camps. One should, however, also have awareness of the fact that even research that nominally challenges bordering practices can inadvertently become big business (see for instance Pendakis 2020 on the massive NGOisation of refugee solidarity in Greece). Many studies have focused on forms of micro-resistance but under-prioritised studying the structural context.

Our point of departure in our research was to use ethnographic and digital material to speak back to system. This brings us to three insights from our studies-here presented as propositions. Firstly that, engaged research is not only about empathising with refugees and migrants and trying to not do harm, or protect them, but also about illuminating the broader social and economic constraints that they face on many scales 
(not just the biopolitical space where the bordering takes place). Secondly, acknowledging that research does not take place in a vacuum but must also take into account the location of the bordering regime where it takes place. We should acknowledge the differences that exist within the European asylum, migration, and deportation regime. Thirdly, that there is also a need for awareness that academia is turning more and more into an industrialised mass production-based enterprise where churning out papers affords you more cultural capital that you can transform into economic capital, and that many research papers are, in fact, about vulnerable groups (such as asylum seekers, trafficked persons, sex workers, unaccompanied minors, precarious workers, and illegalised migrants). So we must be aware that, because of the fact that our output depends on those experiences, there is a stronger imperative to publish less, betterquality research that is not only descriptive and analytical, but also critical and engaged, and as Stierl suggests, accentuates the crisis rather than fixing it.

Turning our gaze to the particular site that caused the discussion at the conference we mentioned in the introduction, we can first question its purpose, what it is, and what it offers. Secondly, ask if a militant research approach or the AoM approach necessitates the use of online platforms? More importantly-do either legitimise it? The platform was created on Facebook in 2014. All posts are written in Arabic. By April 2020, it had more than 330,000 members. The group is one of several, which all aim to support people who need information and support to navigate the European border regimes (see Fischer and Jørgensen, forthcoming b). Other groups offer information on sea conditions (write and share about the sea, weather conditions) but the platform is by far the biggest of such groups.

Users of the group use it as a tool for sharing information. It seems that people use both their own profiles and profiles made for the occasion to post questions. Often a post is made, a question asked, and soon after answers have been given, the post is deleted. The group is a closed group where one has to apply for membership that is approved or declined by one of the administrators. However, a group with more than 330,000 members is de facto open and it is easy to see how anyone could gain access if they wished, including police and border agencies. This is probably a reason why the group rules stipulate that human smugglers have no access, and neither must deals be made with smugglers or brokers. The platform is both a constantly evolving knowledge base of mobility and an 
infrastructure of connectivity, which in our understanding is an example of a mobile commons. We chose deliberately to bring this particular mobile commons into our understanding of deportable persons' struggle against deportation and border regime(s). Not to reveal or outline particular strategies but to emphasise and acknowledge how counter-knowledge is produced and utilised to challenge the (also digital) deportation regimes (De Genova and Peutz 2010).

The ethical dilemmas in online ethnographic research are arguably different from on-site ethnographic research. Donath makes an interesting argument here: "In the physical world there is an inherent unity to the self, for the body provides a compelling and convenient definition of identity. The norm is one body, one identity [...]. The virtual world is different. It is composed of information rather than matter" (Donath 1998). This is something that has to be kept in mind while doing online research, namely that it is a two-way street: on the one hand, people might not know that their posts are being used for research; on the other hand, we do not actually know who is sitting at the laptop making these posts, and with what intention, etc.

People posting on the platform have many reasons to use fake identities, in other words rely on deception, to get the information they require for their journeys. Instead of viewing digital technologies exclusively as enabling monitoring and control of migrants, we should also recognise migrants' capacity for deception within the online world and the creative ways in which they gain access to information in the spirit of the autonomy of migration approach. This leads us to another proposition that may be perceived as controversial. We should, if not reject the surveillance bias, then at least be reflexive about it when studying migrants and other vulnerable groups, for it can inadvertently create a condition of permanent victimhood. We should not harvest different closed groups and sites for data or reveal information, but we should communicate that people react and resist and seek to challenge the deportation machinery.

We conclude this chapter by stating that all social science research is in danger of putting others at risk. This is why we need reflexive and contextualised ethics that allow us to conduct the research we believe could criticise and improve a dehumanising system such as the deportation regime. We should be aware not to make research impossible that could assist in highlighting the brutality of such regimes. 


\section{BIBLIOGRAPHY}

Agustín, Óscar García, and Martin Bak Jørgensen. 2018. Solidarity and the 'Refugee Crisis' in Europe. Cham: Springer.

Ali, Suki. 2006. "Racializing Research: Managing Power and Politics?" Ethnic and Racial Studies 29 (3): 471-486.

Bell, Claudia. 2017. “'We Feel Like the King and Queen': Western Retirees in Bali, Indonesia." Asian Journal of Social Science 45 (3): 271-293.

Birnie, Rutger. 2019. "The Ethics of Resisting Deportation." In Proceedings of the 2018 ZiF Workshop "Studying Migration Policies at the Interface between Empirical Research and Normative Analysis," edited by Matthias Hoesch and Lena Laube, 191-214. ULB Münster (miami.uni-muenster.de). https://doi. org/10.17879/95189423213.

Block, Karen, Elisha Riggs, and Nick Haslam. 2013. Values and Vulnerabilities: The Ethics of Research with Refugees and Asylum Seekers. Toowong, Australia: Australian Academic Press

Bojadžijev, Manuela, and Serhat Karakayali. 2010. "Recuperating the Sideshows of Capitalism: The Autonomy of Migration Today". e-flux journal 17: 1-9.

Boswell, John, Jack Corbett, Kate Dommett, Will Jennings, Matthew Flinders, R. A. W. Rhodes, and Matthew Wood. 2019. "State of the Field: What Can Political Ethnography Tell Us About Anti-Politics and Democratic Disaffection?" European Journal of Political Research 58 (1): 56-71.

Burawoy, Michael. 2005. "For Public Sociology." American Sociological Review 70 (1): 4-28.

Casas-Cortes, Maribel, Sebastian Cobarrubias, and John Pickles. 2015. "Riding Routes and Itinerant Borders: Autonomy of Migration and Border Externalization." Antipode 47 (4): 894-914.

Clifford, James, and George E. Marcus. 1986. Writing Culture: The Poetics and Politics of Ethnography. Berkeley: University of California Press.

De Genova, Nicholas, ed. 2017. The Borders of "Europe": Autonomy of Migration, Tactics of Bordering. Durham, NC: Duke University Press.

De Genova, Nicholas, Glenda Garelli, and Martina Tazzioli, eds. 2018. "Autonomy of Asylum? The Autonomy of Migration Undoing the Refugee Crisis Script." South Atlantic Quarterly 117 (2): 239-265.

De Genova, Nicholas, and Nathalie Peutz, eds. 2010. The Deportation Regime Sovereignty, Space, and the Freedom of Movement. Durham, NC: Duke University Press.

Donath, Judith S. 1998. "Identity and Deception in the Virtual Community." In Communities in Cyberspace, edited by Peter Kollock and Marc Smith. London: Routledge.

Düvell, Franck, Anna Triandafyllidou, and Bastian Vollmer. 2010. "Ethical Issues in Irregular Migration Research in Europe." Population, Space and Place 16 (3): 227-239. 
Fahrendorff, Christian. 2012. "Illegal Indvandring Til Danmark Stiger." Dr.dk, 29.03.2012. Accessed March 11, 2021. http://www.dr.dk/Nyheder/Ind land/2012/03/29/191724.htm.

Fischer, Leandros, and Martin Bak Jørgensen. (Forthcoming a). "Marxist Perspectives on Migration between Autonomy and Hegemony: An Intervention for a Strategic Approach." In Marxism and Migration, edited by Genevieve Ritchie, Sara Carpenter, and Shahrzad Mojab.

Fischer, Leandros, and Martin Bak Jørgensen. (Forthcoming b). "Autonomy of Migration in the Age of Deportation-Migrants' Practices against Deportation." In The Migration Mobile: Border Dissidence, Sociotechnical Resistance and the Construction of Irregularized Migrants, edited by Vasilis Galis, Martin Bak Jørgensen, and Marie Sandberg. Washington, DC: Rowman \& Littlefield.

Flick, Uwe. 2018. An Introduction to Qualitative Research. Newbury Park, CA: Sage.

Foley, Douglas. E. 2002. "Critical Ethnography: The Reflexive Turn." International Journal of Qualitative Studies in Education 15 (4): 469-490.

Gavanas, Anna, and Inés Calzada. 2016. "Multiplex Migration and Aspects of Precarization: Swedish Retirement Migrants to Spain and Their Service Providers." Critical Sociology 42 (7-8): 1003-1016.

Glerup, Marie Rask. 2012. "Ingen kender tal for illegale indvandrere." Detektor Dr.dk, May, 2012. http://www.dr.dk/Pl/Detektor/Udsendelser/2012/05/ $01170052 . \mathrm{htm}$.

Hage, Ghassan. 2009. Waiting Out the Crisis: On Stuckedness and Governmentality. Carlton, VIC: Melbourne University Press.

Halvorsen, Sam. 2015. "Militant Research Against-and-Beyond Itself: Critical Perspectives from the University and Occupy London." Area 47 (4): 466472.

Jacobsen, Karen, and Loren B. Landau. 2003. "The Dual Imperative in Refugee Research: Some Methodological and Ethical Considerations in Social Science Research on Forced Migration.” Disasters 27 (3): 185-206.

Juris, Jeffrey. 2007. "Practicing Militant Ethnography with the Movement for Global Resistance in Barcelona." In Constituent Imagination: Militant Investigations, Collective Theorization, edited by Stevphen Shukaitis, David Graeber, and Erika Biddle, 11-34. Chico, CA: AK Press.

Juris, Jeffrey. 2014. "Activism: Deviation. Fieldsights—Field Notes." Cultural Anthropology Online May 18, 2014.

Jørgensen, Martin Bak. 2012. "Categories of Difference in Science and Policy-Reflections on Academic Practices, Conceptualizations and Knowledge Production." Qualitative Studies 3 (2): 78-96.

Jørgensen, Martin Bak. 2019. “'A Goat That Is Already Dead Is No Longer Afraid of Knives': Refugee Mobilizations and Politics of (Necessary) Interference in Hamburg." Ethnologia Europaea 49 (1): 41-57. 
Jørgensen, Martin Bak, Susi Meret, Annika Lindberg, and José Bayona. 2018. "Reclaiming the Right to Life: Hunger Strikes and Protests in Denmark's Deportation Centres." Open Democracy, January 7, 2018. Accessed March 11, 2021. https://www.opendemocracy.net/en/can-europe-make-it/reclaimi/.

Karakayali, Serhat, and Vassilis Tsianos. 2010. "Transnational Migration and the Emergence of the European Border Regime: An Ethnographic Analysis." European Journal of Social Theory 13 (3): 373-387.

Krause, Ulrike. 2017. "Researching Forced Migration: Critical Reflections on Research Ethics during Fieldwork." Refugee Studies Centre. Working Paper Series (123).

Kumar, Satendra. 2014. "The Promise of Ethnography for the Study of Politics." Studies in Indian Politics 2 (2): 237-242.

Mathers, Andrew, and Mario Novelli. 2007. "Researching Resistance to Neoliberal Globalization: Engaged Ethnography as Solidarity and Praxis." Globalizations 4 (2): 229-249.

Mezzadra, Sandro. 2011. "The Gaze of Autonomy: Capitalism, Migration, and Social Struggles." In The Contested Politics of Mobility: Borderzones and Irregularity, edited by Vicki Squire, 121-142. London: Routledge.

Mezzadra, Sandro, and Brett Neilson. 2013. Border as Method, or, the Multiplication of Labor. Durham, NC, and London: Duke University Press.

Nayak, Anoop. 2006. "After Race: Ethnography, Race and Post-Race Theory." Ethnic and Racial Studies 29 (3): 411-430.

Nimführ, Sarah, and Buba Sesay. 2019. "Lost in Limbo? Navigating (Im)mobilities and Practices of Appropriation of Non-deportable Refugees in the Mediterranean Area." Comparative Migration Studies 7 (1): 1-19.

Papadopoulos, Dimitris, and Vassilis Tsianos. 2013. "After Citizenship: Autonomy of Migration, Organisational Ontology, and Mobile Commons." Citizenship Studies 17 (2): 178-196.

Pendakis, Katherine L. 2020. "Migrant Advocacy under Austerity: Transforming Solidarity in the Greek-Refugee Regime." Journal of Refugee Studies online first https://doi.org/10.1093/jrs/fezll3.

Pittaway, Eileen, Linda Bartolomei, and Richard Hugman. 2010. "'Stop stealing our stories': The ethics of research with vulnerable groups." Journal of Human Rights Practice 2 (2): 229-251.

Polson, Erika. 2016. Privileged Mobilities: Professional Migration, Geo-Social Media, and a New Global Middle Class. Hamburg: Peter Lang.

Rodgers, Graeme. 2004. "'Hanging out' with Forced Migrants: Methodological and Ethical Challenges." Forced Migration Review 21: 48-49.

Rosenblum, Karen, and Toni-Michelle Travis. 2008. The Meaning of Difference: American Constructions of Race, Sex and Gender, Social Class, Sexual Orientation, and Disability. New York, NY: McGraw-Hill Companies. 
Rozakou, Katerina. 2019. "'How Did You Get In?' Research Access and Sovereign Power during the 'Migration Crisis' in Greece." Social Anthropology 27: 68-83.

Scheper-Hughes, Nancy. 1995. "The Primacy of the Ethical: Propositions for a Militant Anthropology." Current Anthropology 36 (3): 409-440.

Shukaitis, S. Stevphen, and David Graeber. 2007. Constituent Imagination: Militant Investigations/Collective Theorization. Edinburgh: AK Press.

Siapera, Eugenia, and Creta, Sarah. 2020. "The Ethics of Media Research with Refugees." In Media Activist Research Ethics, edited by Sandra Jeppesen, and Paola Sartoretto, 221-248. Cham: Palgrave Macmillan.

Stierl, Maurice. 2018. Migrant Resistance in Contemporary Europe. London: Routledge.

Stierl, Maurice. 2020. "Do No Harm? The Impact of Policy on Migration Scholarship." Environment and Planning C: Politics and Space online first. https:// doi.org/10.1177/2399654420965567.

Team Colors Collective, eds. 2010. Uses of a Whirlwind: Movement, Movements, and Contemporary Radical Currents in the United States. Edinburgh: AK Press.

Thomsen, Trine Lund, and Martin Bak Jørgensen. 2012. "Researching Irregular Migration: Concepts, Numbers, and Empirical Findings in a Scandinavian Context." Nordic Journal of Migration Research 2 (4): 275-279.

Thomsen, Trine Lund, Martin Bak Jørgensen, Susi Meret, HelleStenum, and Kirsten Hviid, eds. 2010. Irregular Migration in a Scandinavian Perspective: Maastricht: Shaker Publishers.

Trimikliniotis, Nicos, Parsanoglou Dimitris, and Vassilis Tsianos. 2016. "Mobile Commons and/in Precarious Spaces: Mapping Migrant Struggles and Social Resistance." Critical Sociology 42 (7-8): 1035-1049.

Turton, David. 1996. "Migrants \& Refugees: A Mursi Case Study." In In Search of Cool Ground: War, Flight \& Homecoming in Northeast Africa, edited by Tim Allen, 96-110. London: Africa World Press.

Udlændinge-,Integration- og Boligministeriet. 2016. Tal på udlendingeområdet pr. 31.08.2016. København: Udlændinge-, Integration- og Boligministeriet.

Van Houtum, Henk, and Rodrigo Bueno Lacy. 2020. “The Migration Map Trap. On the Invasion Arrows in the Cartography of Migration." Mobilities 15 (2): 196-219.

Van Liempt, Ilse, and Veronika Bilger, eds. 2009. The Ethics of Migration Research Methodology: Dealing with Vulnerable Immigrants. Sussex, UK: Sussex Academic Press.

Van Liempt, Ilse, and Veronika Bilger. 2018. "Methodological and Ethical Dilemmas in Research Among Smuggled Migrants." In Qualitative Research in European Migration Studies, edited by Ricard Zapata-Barrero, and Evren Yalaz, 269-285. Cham: Springer. 
Venkatesh, Sudhir Alledi. 2013. "The Reflexive Turn: The Rise of First-Person Ethnography." The Sociological Quarterly 54 (1): 3-8.

Wissink, Lieke. 2019. "Material Guides in Ethically Challenging fields: Following Deportation Files." In Secrecy and Methods in Security Research, edited by Marieke de Goede, Esmé Bosma, and Polly Pallister-Wilkins, 291-305. London: Routledge.

Yalaz, Evren, and Ricard Zapata-Barrero. 2018. "Mapping the Qualitative Migration Research in Europe: An Exploratory Analysis." In Qualitative Research in European Migration Studies, edited by Ricard Zapata-Barrero, and Evren Yalaz, 9-31. Cham: Springer.

Zapata-Barrero, Richard, and Evren Yalaz. 2020. "Qualitative Migration Research Ethics: A Roadmap for Migration Scholars." Qualitative Research Journal 20 (3): 269-279.

Open Access This chapter is licensed under the terms of the Creative Commons Attribution 4.0 International License (http://creativecommons.org/licenses/ by $/ 4.0 /)$, which permits use, sharing, adaptation, distribution and reproduction in any medium or format, as long as you give appropriate credit to the original author(s) and the source, provide a link to the Creative Commons license and indicate if changes were made.

The images or other third party material in this chapter are included in the chapter's Creative Commons license, unless indicated otherwise in a credit line to the material. If material is not included in the chapter's Creative Commons license and your intended use is not permitted by statutory regulation or exceeds the permitted use, you will need to obtain permission directly from the copyright holder.

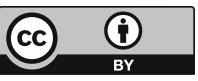

